\title{
The levels of apostosis markers in different HIV infected patients groups
}

\author{
Ilze Eksteina ${ }^{* \dagger}$, Valentina Sondore ${ }^{\dagger}$, Baiba Rozentale, Andrejs Ivanovs, Inga Januskevica, Gunta Sture, \\ Ludmila Viksna
}

From 17th International Symposium on HIV and Emerging Infectious Diseases (ISHEID)

Marseille, France. 23-25 May 2012

\section{Introduction}

HIV-1 infection is characterized by a progressive loss of CD4+ T cells. The role of apoptotic processes was identified recently, but a limited information is available so far. The aim of this study was to compare levels of apoptosis markers - cytokeratin 18 neoepitope (CK18) and cytochrome $\mathrm{C}(\mathrm{CC})$ in different HIV infected patient groups.

\section{Methods}

There were $69 \mathrm{HIV}$ infected patients enrolled in the study and divided into four groups according to CD4+ T cell count and presence of opportunistic infections (OI): 19 patients with CD4+ T cell count above $200 \mathrm{c} / \mathrm{mcl}$ without OI, 15 patients with CD4+ T cell count below $200 \mathrm{c} / \mathrm{mcl}$ without OI, 7 patients with CD4+ T cell count above 200 c/mcl with OI, 28 patients with CD4+ T cell count below $200 \mathrm{c} / \mathrm{mcl}$ with OI. Opportunistic infections included tuberculosis, cryptococcosis, CMV infection, PCP. The serum levels of cytokeratin 18 neoepitope and cytochrome $\mathrm{C}$ were determined. Comparisons between groups were made using paired $\mathrm{T}$ - test.

\section{Results}

CC levels were not significantly different between groups with CD4+ cell count above and below $200 \mathrm{c} / \mathrm{mcl}$ (with opportunistic infections $0,5>p>0,4$, without opportunistic infections $\mathrm{p}=0,5)$. Levels of $\mathrm{CC}$ were not significantly influenced by presence of opportunistic infections (with CD4+ cell count above $200 \mathrm{c} / \mathrm{mcl} \mathrm{p}=0,6$, with $\mathrm{CD} 4+$ cell count below $200 \mathrm{c} / \mathrm{mcl} \mathrm{p}=0,7)$. We found significant diference of CK18 levels between group without opportunistic infections and CD $4+$ cell count above $200 \mathrm{c} / \mathrm{mcl}(210,58$ $\pm 26,98 \mathrm{u} / \mathrm{l})$ and group without opportunistic infections

\footnotetext{
* Correspondence: ilze.viruss@inbox.lv

† Contributed equally

Infectologist at Infectology Center of Latvia, Riga, Latvia
}

and CD4+ cell count above $200 \mathrm{c} / \mathrm{mcl}(132,95 \pm 14,09 \mathrm{u} / \mathrm{l})$, $\mathrm{p}=0,02$, as well as between group without opportunistic infections and CD4+ cell count below $200 \mathrm{c} / \mathrm{mcl}(132,95$ $\pm 14,09 \mathrm{u} / \mathrm{l}$ ) and group with opportunistic infections and CD $4+$ cell count below $200 \mathrm{c} / \mathrm{mcl}(174,56 \pm 20,83 \mathrm{u} / \mathrm{l})$, $0.02>\mathrm{p}>0.01$.

\section{Conclusion}

The results obtained from our study demonstrate elevation of levels of apoptosis serum markers early in HIV infection which anticipate further decrease of CD4 cell count.

Published: 25 May 2012

\section{doi:10.1186/1742-4690-9-S1-P20}

Cite this article as: Eksteina et al:: The levels of apostosis markers in different HIV infected patients groups. Retrovirology 2012 9(Suppl 1):P20.

\section{Submit your next manuscript to BioMed Central and take full advantage of: \\ - Convenient online submission \\ - Thorough peer review \\ - No space constraints or color figure charges \\ - Immediate publication on acceptance \\ - Inclusion in PubMed, CAS, Scopus and Google Scholar \\ - Research which is freely available for redistribution \\ Submit your manuscript at www.biomedcentral.com/submit}

